\title{
SYNERGISTIC ACTIVITY OF AMPICILLIN AND CLOXACILLIN
}

\author{
PROTECTIVE EFFECT OF CLOXACILLIN ON ENZYMATIC \\ DEGRADATION OF AMPICILLIN BY PENICILLINASE, \\ AND THERAPEUTIC ACTIVITY OF MIXTURES \\ OF AMPICILLIN AND CLOXACILLIN
}

\author{
Minoru Nishida, Yasuhiro Mine \\ Research Laboratories, Fujisawa Pharmaceutical Co., Ltd., \\ Osaka, Japan \\ and Shogo KuwAhara \\ Department of Microbiology, Toho University \\ School of Medicine, Tokyo, Japan
}

(Received for publication February 15, 1969)

\begin{abstract}
A mixture of ampicillin (aminobenzyl penicillin, AB-PC) and cloxacillin (methylchlorophenylisoxazolyl penicillin, MCI-PC) showed an excellent bactericidal activity even at low concentrations in which either of the penicillins alone did not have any activity against a clinically isolated strain of Escherichia coli, resistant to both of these penicillins. In this case, the microbial degradation of $\mathrm{AB}-\mathrm{PC}$, caused by penicillinase ( $\mathrm{PC}-$ ase), was strongly inhibited in the presence of MCI-PC. The enzymatic hydrolysis of AB-PC by extracellular and cell-bound PC-ase, obtained from an AB-PC resistant strain of Staphylococcus aureus, was also inhibited in the presence of MCI-PC. Against that, under comparable conditions, penicillin $\mathrm{G}$ (PC-G) was almost completely destroyed by cell-bound $\mathrm{PC}$-ase from this organism. An in vivo synergism was observed when mixtures of $\mathrm{AB}-\mathrm{PC}$ and MCI-PC were applied for the treatment of mice challenged with a clinically isolated strain of $E$. coli resistant to both of these penicillins. Similar results were obtained in the treatment of mice experimentally infected with a strain of Staphylococcus aureus, which is highly resistant to AB-PC, but sensitive to MCI-PC.
\end{abstract}

A decrease in the rate of hydrolysis of methicillin (dimethoxyphenyl penicillin, DMP-PC) by staphylococcal penicillinase (PG-ase) was first noted by RoLinson and his co-workers ${ }^{1)}$. At the same time, Gourevitch et $a l .^{2)}$ demonstrated that the reaction of staphylococcal $\mathrm{PC}$-ase with $\mathrm{PC}$-ase resistant penicillins, such as DMP-PC and oxacillin (methylphenylisoxazolyl penicillin), led to an inactivation of the enzyme, and that there was a direct relationship between the amount of DMP-PC decomposed and the degree of inactivation of the enzyme.

The present investigation was undertaken to study the protective effect of cloxacillin (methylchlorophenylisoxazolyl penicillin, MCI-PG), a PC-ase resistant penicillin, on the enzymatic hydrolysis of ampicillin (aminobenzyl penicillin, AB-PC) by $\mathrm{PC}$-ase obtained from some clinically isolated bacteria. Furthermore, the effect 
of MCI-PG in vitro was confirmed by the fact that the therapeutic activity in mice was enhanced by the combination of both penicillins.

\section{Materials and Methods}

1. Substances used: AB-PC (Beecham), MCI-PC (Beecham) and potassium penicillin $\mathrm{G}(\mathrm{PC}-\mathrm{G})$ were used in these experiments. The commercial PC-ase preparation (Tokyo Kenbikyoin) had an activity of 400,000 u/vial.

2. Organisms used and preparation of extracellular and cell-bound PC-ase: Staphylococcus aureus No. 39 was isolated from a patient at the Institute for Medical Science, and Staph. aureus T-5 and Escherichia coli T-20 were supplied by Toho University. E. coli No. 11 was isolated from a patient at Kyoto Municipal Hospital.

The extracellular and cell-bound PC-ases were prepared as follows: Brain-heart infusion broth $(80 \mathrm{ml})$ was inoculated each with one loopful of AB-PC resistant strains of Staph. aureus or E. coli isolated from patients, then incubated with shaking at $37^{\circ} \mathrm{C}$ for 4 hours. Each culture was centrifuged $(13,000 \times G, 20 \mathrm{~min}$.) and the supernatant was used as the extracellular PC-ase. The sedimented cells were washed three times with $0.1 \mathrm{M}$ phosphate buffer ( $\mathrm{pH} \mathrm{7.0)}$ and resuspended in this buffer $(80 \mathrm{ml})$. The cell suspensions were sonicated for 30 minutes (E. coli) or 90 minutes (Staph. aureus). The supernatant from the centrifugation $(1,500 \times G, 15 \mathrm{~min}$.) was used as the cell-bound PC-ase.

3. Incubation of penicillins with enzymes: Sufficient $A B-P C$ solution $(10,000 \mathrm{mcg} / \mathrm{ml})$ and/or MCI-PC solution $(10,000 \mathrm{mcg} / \mathrm{ml})$ was added to tubes containing $10 \mathrm{ml}$ solution of the commercial PC-ase $(10,000 \mathrm{u} / \mathrm{ml}$ ) in $0.1 \mathrm{M}$ phosphate buffer ( $\mathrm{pH} 7.0$ ), to give the desired final concentration of penicillin(s) after adjustment with buffer to a total volume of $20 \mathrm{ml}$. The mixtures were allowed to react with shaking for 1 or 3 hours at $37^{\circ} \mathrm{C}$. After termination of the reaction by boiling in a water bath for 8 minutes, an aliquot of the mixture was used for the determination of the rate of penicillins inactivation.

In experiments with $\mathrm{PC}$-ase prepared from staphylococci or E. coli, $1 \mathrm{ml}$ of AB-PC solution $(10,000 \mathrm{mcg} / \mathrm{ml})$ and/or $1 \mathrm{ml}$ of $\mathrm{MCI}-\mathrm{PC}$ solution $(5,000 \mathrm{mcg} / \mathrm{ml})$ was mixed with $18 \mathrm{ml}$ of the extracellular or the cell-bound $\mathrm{PC}$-ase solutions. Eventually the resulting mixtures were adjusted with buffer to a total volume of $20 \mathrm{ml}$, and were incubated for different periods of time at $37^{\circ} \mathrm{C}$.

4. Microbioassay: The rates of hydrolysis, in the mixture of both penicillins, were determined by a disc method using E. coli NIHJ for AB-PC and Staph. aureus No. 20 for MCI-PC. Staph. aureus No. 20 is resistant to AB-PC but sensitive to MCI-PC, so MCI-PC in the mixture can be assayed without being disturbed by AB-PC.

5. Determination of viable cell count: Nutrient broth containing AB-PC with or without MCI-PC at the concentrations mentioned below was inoculated with an overnight culture of E. coli No. 11 to give a viable cell count of $10^{7} \mathrm{cells} / \mathrm{ml}$, and was incubated with shaking in water-bath for 24 hours at $37^{\circ} \mathrm{C}$. Small samples were withdrawn at intervals, and tenfold serial dilutions of the samples were mixed with nutrient agar in petri dishes. Colonies of viable cells were counted after the incubation ( 24 hours, $37^{\circ} \mathrm{C}$ ).
(1) $\mathrm{AB}-\mathrm{PC} 40 \mathrm{mcg} / \mathrm{ml}$
(2) MCI-PC $40 \mathrm{mcg} / \mathrm{ml}$
(3) AB-PC $(20 \mathrm{mcg} / \mathrm{ml})+\mathrm{MCI}-\mathrm{PC}(20 \mathrm{mcg} / \mathrm{ml})$

6. Preincubation of PC-ase with MCI-PC: The cell-bound PC-ases obtained from Staph. aureus No. 39 and E. coli T-20, were incubated with MCI-PC for different time intervals preceding the experiment. AB-PC $(1 \mathrm{mg} / \mathrm{ml})$ or $\mathrm{PC}-\mathrm{G}(1 \mathrm{mg} / \mathrm{ml})$ as substrates were added to the mixture which was incubated for 1 hour at $37^{\circ} \mathrm{C}$. The rates of hydrolysis of these substrates were determined by the iodometric method.

7. Experimental treatment of mice infected with some clinically isolated strains of E. coli and Staph. aureus: The combined activity of AB-PC and MCI-PC in vivo was studied by using mice infected with the clinically isolated strains of E. coli and Staph. aureus. Seven mice (ICR-strain, $21 \sim 23 \mathrm{~g}$ ) of each group were challenged intravenously 
(Staph. aureus) or intraperitoneally (E. coli) with $0.5 \mathrm{ml}$ of the bacterial suspensions (viable cell count; E. coli $5 \times 10^{8}$, Staph. $5 \times 10^{6}$ ). The penicillins were subcutaneously administered 1 and 4 hours after the infection. The mice treated were observed for 14 days, and the therapeutic effect of the penicillins was expressed as $C D_{50}$.

\section{Results}

1. Bactericidal Activity of Both Penicillins in Combination against a Clinically Isolated Strain of E. coli and

Microbial Degradation of AB-PG

The bactericidal activities of AB-PC, MCI-PC and the 1:1 combination of these penicillins against a highly resistant strain of $E$. coli No. 11 (minimum inhibitory concentration: AB-PC, MCI-PC $400 \mathrm{mcg} / \mathrm{ml}$ ) were compared. The results are shown in Fig. 1.

When AB-PC or MCI-PC respectively was added to the media at a concentration of $40 \mathrm{mcg} / \mathrm{ml}$, the bacterial growth was not inhibited since the viable cell counts increased similar to that of the control. On the other hand, in the presence of AB-PC (20 $\mathrm{mcg} / \mathrm{ml})$ and MGI-PG $(20 \mathrm{mcg} / \mathrm{ml})$, each concentration corresponding to one-twentieth of the MIC, the viable cell count in the medium decreased to $10^{5}$ cells $/ \mathrm{ml}$ from $10^{7}$ cells/ml after incubation. These results indicate that the bactericidal activity is synergistically enhanced by the combination of AB-PG and MCI-PC.

The rate of microbial degradation of $\mathrm{AB}-\mathrm{PC}$ was simultaneously determined. As shown in Fig. 1, AB-PG was not substantially degraded by E. coli No. 11 in the presence of MCI-PG during 3- or 5- hours of incubation, but AB-PC was markedly inactivated in the absence of MCI-PC.

It is suggested from these results that the enhanced bactericidal activity of the combination of AB-PG and MGI-PG is due to inactivation of PG-ase by MCI-PC.

2. Protective Effect of MCI-PG on Enzymatic Degradation of $\mathrm{AB}-\mathrm{PG}$ by $\mathrm{PG}-$ ase

(1) Commercial penicillinase

The protective activity of MCI-PC on the degradation of $\mathrm{AB}-\mathrm{PC}$ was studied with a commercial $\mathrm{PG}$-ase. The results given in Table 1 demonstrate that ABPG alone was almost completely destroyed after 3 hours of incubation, while MCI-PG alone at concentrations of 250 or $500 \mathrm{mcg} / \mathrm{ml}$, was scarcely affected under the same condition. On the other hand, the degradation of AB-PC in the presence of MCI-PG at different combination $(1: 1,1: 2,2: 1)$ was considerably inhibited in comparison with that of
Fig. 1. Bactericidal activity of $\mathrm{AB}-\mathrm{PC}$ and MCI-PC against a clinically isolated strain of $E$. coli (No. 11) and microbial degradation of $\mathrm{AB}-\mathrm{PC}$.

MIC: AB-PC $400 \mathrm{mcg} / \mathrm{ml}$; MCI-PC $>400 \mathrm{mcg} / \mathrm{ml}$

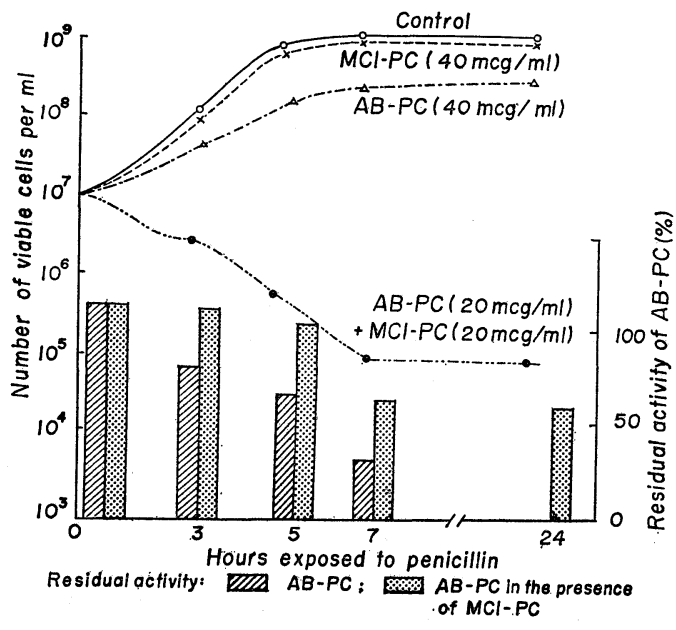


AB-PC alone. However, the relationship between the extent of degradation of $\mathrm{AB}-$ $\mathrm{PC}$ and the optimal proportion of both penicillins mixed could not be established under this condition.

(2) Staphylococcal penicillinase

(a) Extracellular penicillinase: According to the procedure described above, the protective effect of MCI-PC on the enzymatic degradation of $\mathrm{AB}-\mathrm{PC}$ by the extracellular PC-ase, was studied (Table 2).

AB-PG (500 $\mathrm{mcg} / \mathrm{ml})$, added to the supernatant of centrif uged culture medium, was rapidly degraded by extracellular PG-ase to an extent of $68 \%, 93 \%$ and $99 \%$ after $0.5,1$ and 2 hours of incubation. However, MCIPC $(250 \mathrm{mcg} / \mathrm{ml})$ did not suffer any decrease in activity under these conditions.

While AB-PG $(500 \mathrm{mcg} /$
Table 1. Protective effect of MCI-PC on enzymatic degradation of $\mathrm{AB}-\mathrm{PC}$ by commercial penicillinase

\begin{tabular}{|c|c|c|c|c|}
\hline & \multirow{2}{*}{ Penicillins } & \multirow{2}{*}{ Substrates } & \multicolumn{2}{|c|}{$\begin{array}{c}\text { Rates of } \\
\text { degradation** }\end{array}$} \\
\hline & & & $1 \mathrm{hr}$. & $3 \mathrm{hrs}$. \\
\hline \multirow{4}{*}{$\begin{array}{l}\text { PC-ase* } \\
5,000 \\
\quad \mathrm{u} / \mathrm{ml}\end{array}$} & $\begin{array}{l}\text { AB-PC } 500 \mathrm{mcg} / \mathrm{ml}+ \\
\mathrm{MCI}-\mathrm{PC} 500 \mathrm{mcg} / \mathrm{ml}\end{array}$ & $\begin{array}{l}\mathrm{AB}-\mathrm{PC} \\
\mathrm{MCI}-\mathrm{PC}\end{array}$ & $\begin{array}{c}25 \% \\
0\end{array}$ & $\begin{array}{c}55 \% \\
7\end{array}$ \\
\hline & $\begin{array}{l}\text { AB-PC } 500 \mathrm{mcg} / \mathrm{ml}+ \\
\mathrm{MCI}-\mathrm{PC} 1,000 \mathrm{mcg} / \mathrm{ml}\end{array}$ & $\begin{array}{l}\mathrm{AB}-\mathrm{PC} \\
\mathrm{MCI}-\mathrm{PC}\end{array}$ & $\begin{array}{r}39 \\
0\end{array}$ & $\begin{array}{r}48 \\
0\end{array}$ \\
\hline & $\begin{aligned} \text { AB-PC } 500 \mathrm{mcg} / \mathrm{ml}+ \\
\text { MCI-PC } 250 \mathrm{mcg} / \mathrm{ml}\end{aligned}$ & $\begin{array}{l}\mathrm{AB}-\mathrm{PC} \\
\mathrm{MCI}-\mathrm{PC}\end{array}$ & $\begin{array}{r}45 \\
0\end{array}$ & $\begin{array}{r}54 \\
8\end{array}$ \\
\hline & $\begin{array}{l}\text { AB-PC } 500 \mathrm{mcg} / \mathrm{ml} \text { alone } \\
\text { MCI-PC } 500 \mathrm{mcg} / \mathrm{ml} \text { alone } \\
\text { MCI-PC } 250 \mathrm{mcg} / \mathrm{ml} \text { alone }\end{array}$ & $\begin{array}{l}\mathrm{AB}-\mathrm{PC} \\
\mathrm{MCI}-\mathrm{PC} \\
\mathrm{MCI}-\mathrm{PC}\end{array}$ & $\begin{array}{r}58 \\
0 \\
0\end{array}$ & $\begin{array}{r}83 \\
0 \\
9\end{array}$ \\
\hline
\end{tabular}

* Tokyo Kenbikyoin 400,000 u/vial

** Disc method

Table 2. Protective effect of MCI-PC on enzymatic degradation of $\mathrm{AB}-\mathrm{PC}$ by staphylococcal penicillinase (No. 39)

\begin{tabular}{c|c|c|c|c}
\hline \multirow{3}{*}{ Enzyme } & Penicillins & \multicolumn{3}{|c}{ Rates of degradation* } \\
\cline { 2 - 5 } & & $0.5 \mathrm{hr}$. & $1 \mathrm{hr}$. & $2 \mathrm{hrs}$. \\
\hline \multirow{5}{*}{ Extracellular } & AB-PC $500 \mathrm{mcg} / \mathrm{ml}$ & $68 \%$ & $93 \%$ & $99 \%$ \\
& MCI-PC $250 \mathrm{mcg} / \mathrm{ml}$ & 0 & 0 & 0 \\
& AB-PC $500 \mathrm{mcg} / \mathrm{ml}+$ & 0 & 0 & 52 \\
& (MCI-PC $250 \mathrm{mcg} / \mathrm{ml})$ & & & \\
\hline \multirow{5}{*}{ Cell-bound } & AB-PC $500 \mathrm{mcg} / \mathrm{ml}$ & 30 & 96 & 99 \\
& MCI-PC $250 \mathrm{mcg} / \mathrm{ml}$ & 0 & 0 & 8 \\
& AB-PC $500 \mathrm{mcg} / \mathrm{ml}+$ & 22 & 32 & 46 \\
& (MCI-PC $250 \mathrm{mcg} / \mathrm{ml})$ & & & \\
\hline
\end{tabular}

* Disc method

$\mathrm{ml}$ ), incubated with extracellular PC-ase in the presence of MCI-PG $(250 \mathrm{mcg} / \mathrm{ml})$, was not affected within 1 hour of incubation, $52 \%$ of the initial amount was degraded after 2 hours incubation. These results indicate that MCI-PC prevents the enzymatic degradation of AB-PC by extracellular PC-ase, which was released from a PC-resistant strain of Staph. aureus (No. 39).

(b) Cell-bound penicillinase: The incubation of AB-PC (500 mcg/ml) with cellbound PG-ase of Staph. aureus No. 39 resulted in an extensive inactivation of this penicillin after $1 \sim 2$ hours of incubation, whereas MCI-PG was largely unaffected under the same condition. When AB-PC $(500 \mathrm{mcg} / \mathrm{ml})$ was incubated with the enzyme in the presence of MCI-PG $(250 \mathrm{mcg} / \mathrm{ml})$, the degradation of AB-PG was markedly inhibited in comparison with its destruction in the absence of MCI-PC. Thus, the antibiotic activity of $\mathrm{AB}-\mathrm{PC}$ was diminished by $32 \%$ in 1 hour or $46 \%$ in 2 hours. 
3. Protective effect of MGI-PG from Inactivation of $\mathrm{AB}-\mathrm{PC}$ and $\mathrm{PG}-\mathrm{G}$ by $\mathrm{PG}$-ase

In order to determine whether the protective effect of MGI-PC from enzymatic inactivation of AB-PC also applies to PG-G, the rates of the enzymatic degradation of AB-PG and PC-G were compared in the presence of MCI-PG (Table 3). When the inhibitor (MCI-PC, $4 \mathrm{mg} / \mathrm{ml}$ ) was added at zero time to the incubation mixture of the substrate (AB-PC, $1 \mathrm{mg} / \mathrm{ml}$ ) with $\mathrm{PC}$-ase $(0.02 \mathrm{mg} / \mathrm{ml})$, a marked difference was found between the rates of hydrolysis of $\mathrm{AB}-\mathrm{PC}$ and $\mathrm{PC}-\mathrm{G}$ by the cell-bound $\mathrm{PC}$-ase from Staph. aureus No. 39; while PC$\mathrm{G}$ was almost completely hydrolysed (residual activity, $3 \%$ ), $53 \%$ of the original activity of AB-PC was left intact under this condition. When $\mathrm{PC}$-ase was preincubated with MCI-PC for 5 20 minutes before addition of the substrates, the difference of protection from inactivation between the two penicillins largely disappeared.

Preincubation of cell-bound PC-ase from E. coli T-20 with MCI-PC (Table 4), did not result in much more protection of $\mathrm{AB}-$ $\mathrm{PC}$, compared with the corresponding experiments with PG-ase from Staph. aureus No. 39. Again, however, AB-PC was protected more effectively than PC-G.

4. Therapeutic Activity of a Combination of AB-PG with MCI-PG against Experimental Infection in Mice

Mice were challenged with E. coli No. 11 which was highly resistant to both penicillins (MIC: AB-PC $400 \mathrm{mcg} / \mathrm{ml}, \mathrm{MCI}-\mathrm{PC}>400 \mathrm{mcg} / \mathrm{ml}$ ). As shown in Table 5, when $\mathrm{AB}-\mathrm{PG}$ alone, subcutaneously administered twice after infection, resulted in a

Table 3. Inactivation of staphylococcal $\beta$-lactamase (No. 39) by contact with MCI-PC prior to addition of $\mathrm{AB}-\mathrm{PC}$ or $\mathrm{PC}-\mathrm{G}$

\begin{tabular}{c|c|c}
\hline \multirow{2}{*}{$\begin{array}{c}\text { Preincubation } \\
\text { (minutes) }\end{array}$} & \multicolumn{2}{|c}{ Substrates and residual activity* } \\
\cline { 2 - 3 } & AB-PC & PC-G \\
\hline 60 & $92 \%$ & $92 \%$ \\
40 & 82 & 84 \\
20 & 75 & 63 \\
10 & 75 & 61 \\
5 & 65 & 58 \\
0 & 53 & 3 \\
\hline
\end{tabular}

Table 4. Inactivation of Escherichia coli (T-20) $\beta$-lactamase by contact with MCI-PC prior to addition of $\mathrm{AB}-\mathrm{PC}$ or $\mathrm{PC}-\mathrm{G}$

\begin{tabular}{c|c|c}
\hline $\begin{array}{c}\text { Preincubation } \\
\text { (minutes) }\end{array}$ & \multicolumn{2}{|c}{ Substrates and residual activity* } \\
\cline { 2 - 3 } & AB-PC & PC-G \\
\hline 60 & $79 \%$ & $57 \%$ \\
40 & 76 & 57 \\
20 & 74 & 55 \\
10 & 69 & 55 \\
5 & 66 & 55 \\
0 & 64 & 55 \\
\hline
\end{tabular}

* Iodometric assay

Table 5. Therapeutic activity of $\mathrm{AB}-\mathrm{PC}$ and $\mathrm{MCI}-\mathrm{PC}$ in combination on experimentally infected mice

\begin{tabular}{l|c|c}
\hline \multirow{2}{*}{ Treatment* } & \multicolumn{2}{|c}{$\begin{array}{c}\mathrm{CD}_{50} \text { dose of total penicillins } \\
(\mathrm{mg} / \mathrm{kg})\end{array}$} \\
\cline { 2 - 3 } & E. coli No. 11** & $\begin{array}{c}\text { Staph. aureus } \\
\text { T-5** }\end{array}$ \\
\hline AB-PC alone & $>1,740$ & $>600$ \\
MCI-PC alone & $>870$ & $350 \sim 469$ \\
AB-PC+MCI-PC (2:1) & 330 & 347 \\
AB-PC+MCI-PC (1:1) & 507 & 424 \\
\hline
\end{tabular}

* Penicillins were injected subcutaneously 1 and 4 hours after challenge.

** MIC: Staph. aureus T-5 (AB-PC, $50 \mathrm{mcg} / \mathrm{ml}$; MCI$\mathrm{PC}, 0.5 \mathrm{mcg} / \mathrm{ml})$

E. coli No. 11 (AB-PC, $400 \mathrm{mcg} / \mathrm{ml}$; MCI-PC, $>400 \mathrm{mcg} / \mathrm{ml}$ )

aph. aureus No. 39. Again, however, 
$\mathrm{CD}_{50}$ value of $>1,740 \mathrm{mg} / \mathrm{kg}$, indicating that $\mathrm{AB}-\mathrm{PC}$ is ineffective in the treatment of the mice infected with this strain. The administration of MGI-PG alone was also not effective $\left(\mathrm{CD}_{50},>870 \mathrm{mg} / \mathrm{kg}\right)$ under the same condition. However, the $\mathrm{CD}_{50}$ value resulting from the combination of AB-PC with MCI-PG $(2: 1)$ was $330 \mathrm{mg} / \mathrm{kg}$ and $507 \mathrm{mg} / \mathrm{kg}$ respectively in the case of $1: 1$ combination of these penicillins. Thus, the therapeutic effect of both penicillins in combination was superior to that obtained with $\mathrm{AB}-\mathrm{PG}$ or MCI-PG alone. This indicates an in vivo synergism between AB-PG and MCI-PG against a PC-resistant strain of $E$. coli.

In the treatment of mice infected with Staph. aureus $\mathrm{T}-5$, which is highly resistant to $\mathrm{AB}-\mathrm{PG}$ but sensitive to $\mathrm{MCI}-\mathrm{PC}$, the administration of MCI-PG alone showed a considerable effect $\left(\mathrm{CD}_{50}, 350 \sim 469 \mathrm{mg} / \mathrm{kg}\right)$, but a treatment with $\mathrm{AB}-\mathrm{PC}$ alone had no effect $\left(\mathrm{CD}_{50},>600 \mathrm{mg} / \mathrm{kg}\right)$. On the other hand, when $\mathrm{AB}-\mathrm{PC}$ and MCI-PC were given in combination (2:1), the therapeutic effect $\left(\mathrm{CD}_{50}, 347 \mathrm{mg} / \mathrm{kg}\right)$ was comparable to that of MCI-PG alone, and a similar effect was obtained with the $1: 1$ combination of both penicillins.

In view of the fact that the MCI-PC portion of the AB-PC/MCI-PG mixtures, administered to the animals, represented only about a half or one third of the total dose of penicillin, it seems to be justified to explain the therapeutic effects, obtained with the mice infected with Staph. aureus $\mathrm{T}-5$, by a true synergism between the two penicillins.

\section{Discussion}

It is known that some penicillins of the isoxazolyl group prevent the enzymatic degradation of some PC-ase sensitive penicillins by inactivating $\mathrm{PC}-$ ase. ${ }^{1,2,3,4)}$ In the present study, it was found that the enzymatic degradation of $\mathrm{AB}-\mathrm{PC}$ in vitro was also prevented by MCI-PC.

A trial to clarify the enhancement of the therapeutic activity in vivo by a combination of an isoxazolyl penicillin and AB-PC was already carried out by $\mathrm{BACH}$ et al. ${ }^{5)}$, who noted a synergism between ampicillin and dicloxacillin in the treatment of mice infected with Shigella flexneri under a limited condition, such as the repeated administration of the penicillins (4 times) at an early stage of infection. In the experimental infection with Proteus morganii NCTC-235, able to hydrolyze cephaloridine, O'C $\mathrm{ALLAGHAM}^{6)}$ found an in vivo synergism of cephaloridine and some cephalosporin derivatives, resistant to $\beta$-lactamase, by the repeated administration of both cephalosporins ( 5 times) after infection.

In the present study, $\mathrm{AB}-\mathrm{PC}$ and MCI-PC administered in combination showed an enhanced therapeutic activity in mice infected with some AB-PC resistant strains of Staph. aureus and E. coli. In our experiments, the synergistic activity of AB-PC and MCI-PC against $E$. coli was more pronounced than that reported previously for this organism by the other researchers. In this regard, however, the difference in sensitivity of the bacteria used, properties of $\mathrm{PC}$-ase produced, and other factors should be taken into account. Furthermore, if the synergistic activity of $\mathrm{AB}-\mathrm{PC}$ and $\mathrm{MCI}-\mathrm{PC}$ in the infected mice is based on the inhibiting effect of MCI-PC against PC-ase from the bacteria, further studies remain to be done with respect to a correlation between the distribution of $\mathrm{PC}$-ase in the infected animal and the degradation of $\mathrm{AB}-\mathrm{PC}$ in vivo by the distributed enzyme. 


\section{Acknowledgement}

The authors wish to express their sincere thanks to Dr. Nakano, Director of Fujisawa Pharmaceutical Co., Ltd. and Dr. Kumada for guidance and encouragement.

\section{References}

1) Rolinson, G. N.; S. Steqens, F. R. Batchelor, J. Cameron-Wood \& E. B. Chain: Bacteriological studies on a new penicillin-BRL. 1241. Lancet 1960-2: 564 567, 1960

2) Gourevitch A.; T. A. Pursiano \& J. Lein: Inactivation of staphylococcal penicillinase by reaction with resistant penicillins. Nature $195: 496 \sim 497,1962$

3) Hamilton-Miller, J.M.T.: Penicillinase from Klebsiella aerogenes. A comparison with penicillinases from gram-positive species. Biochem. J. $87: 209 \sim 214,1963$

4) Hamilton-Miller, J.M.T. \& J. T. Smith: Inhibition of penicillinases from Gram-positive and Gram-negative bacteria by substrate analogues. Nature $201: 999 \sim 1001,1964$

5) Bach, J. A.; N. Buono, D. Chisholm, K. E. Price, T. A. Pursiano \& A. Gourevitch: In vitro and in vivo synergism of mixtures of penicillins. Antimicr. Agents \& Chemoth.-1966:328 336, 1967.

6) O’Callaghan, C. H.; P. W. Muggleton, S. M. Kirby \& D. M. Ryan: Inhibition of $\beta$-lactamase decomposition of cephaloridine and cephalothin by other cephalosporins. Antimicr. Agents \& Chemoth. $-1966: 337 \sim 343,1967$ 